\title{
Retraction Note to: The characteristics of urban soil deposition and financial management of state-owned assets based on big data system
}

\author{
Jianfei Huang ${ }^{1}$
}

Published online: 12 November 2021

(c) Saudi Society for Geosciences 2021

Retraction Note to: Arabian Journal of Geosciences (2021) 14: 1383

https://doi.org/10.1007/s12517-021-07641-y

The Editor-in-Chief and the Publisher have retracted this article because the content of this article is nonsensical. The peer review process was not carried out in accordance with the Publisher's peer review policy. The author has not responded to correspondence regarding this retraction.

The original article can be found online at https://doi.org/10.1007/ s12517-021-07641-y.

Jianfei Huang

huangjianfei8332@163.com

1 Financial Department, Fujian Polytechnic of Information Technology, Fuzhou 350003, China 